\title{
COL4A6 wt Allele
}

National Cancer Institute

\section{Source}

National Cancer Institute. COL4A6 wt Allele. NCI Thesaurus. Code C52482.

Human COL4A6 wild-type allele is located in the vicinity of Xq22 and is approximately 284 $\mathrm{kb}$ in length. This allele, which encodes collagen alpha-6 (IV) chain protein, is involved in the regulation of the conformation of the basement membrane. Deletion of the gene is associated with diffuse leiomyomatosis with Alport syndrome. 